\title{
Syrian Refugee Middle School Students' Perceptions of the History Subjects Taught in Social Studies Lessons
}

\author{
Osman Akhan \\ Akdeniz University, Antalya, Education Faculty, TURKEY
}

Received: 11 February 2021 • Accepted: 12 April 2021 • Published Online: 26 April 2021

\begin{abstract}
The purpose of this research is to determine perceptions of refugee middle school students in Turkey about history subjects taught in social studies classes. Accordingly, the study was designed in the phenomenology model, a qualitative research method. The sample included 58 middle school $7^{\text {th }}$ and $8^{\text {th }}$ grade Syrian students (28 female, 30 male) legally registered in Gaziantep province of Turkey in 2019-2020. Convenience sampling method was used to select the schools, and criterion sampling, a purposive sampling method, was used to select the sample from students in these schools. Research data were collected with a questionnaire form containing open-ended questions created by the researcher, and subjected to descriptive analysis. Considering the results of the research, one can say that the students could remember the history subjects they learned, and found Ottoman history subjects more interesting. However, they found history lessons boring, and studying history subjects was not effective in creating patriotic perceptions.
\end{abstract}

Keywords: refugee, Syrian, middle school students, history.

\section{Introduction}

People may voluntarily migrate to other countries in order to have a better life, bu they may also be forced to migrate to other countries due to extraordinary reasons such as war. The issue of migration, which is as old as human history, has created a new group of refugee children due to the increase in the population of refugee children in many countries over time. This situation has made it necessary for countries to take children into account in their immigration policies. Consequently, education policies for immigrant children have gained currency (Taşkın \& Erdemli, 2018).

Many Syrians had to leave their country and migrated to various countries as a result of the civil war that broke out in Syria in 2011. It can be said that the Syrian refugee crisis is the biggest refugee crisis in the world. Countries like Turkey, Jordan and Lebanon have been severely affected by waves of immigration (Bicer, 2017). The unending civil war conditions in Syria, without a ray of hope for peace in the offing, caused the refugees in Turkey to settle in Turkey (Kılc1, cited in Çepni \& Kilinc, 2017). Previously hosting large numbers of refugees, Turkey pursued an unconditional "open borders policy" for those fleeing the civil war in Syria, just as it did for those fleeing the military conflict and occupation in Iraq (Aydin \& Kumar, 2017). Since the beginning of the Syrian crisis in 2011, the number of refugees in Turkey increased gradually, and it was hosting over 3 million Syrian refugees as of 2016-2017 (Tezel McCarthy, 2018).

(C) Authors. Terms and conditions of Creative Commons Attribution 4.0 International (CC BY 4.0) apply. Correspondence: Osman Akhan, Akdeniz University, Faculty of Education, Antalya, TURKEY. E-mail: osmanakhan@akdeniz.edu.tr. 
Education has been a human right since the 1948 Universal Declaration of Human Rights. While refugee students are being planned to be integrated into the society they are in, prioritizing education, some negative behaviors may occur depending on the psychological conditions they experience. Considering that the Syrian refugee children have been traumatized by the violence they were subjected to, schools can serve as areas that can help refugee children escape from various threats (such as violence, abuse, child labor, child marriage) and help them return to normal and routine life after trauma. This fact is reason enough for the world to invest more resources in providing quality education to refugees (Gümüşten, 2017; Kiwan, 2021; Le, 2019). In addition, schools are an important factor in terms of social cohesion and integration of refugee children (Kağnıcı, 2017). In short, the inclusion of refugees in national education systems has been adopted as a standard global policy approach (Dryden-Peterson, 2020).

According to the data of the Republic of Turkey Interior Ministry General Directorate of Immigration Administration, the population of Syrians in the 5-17 age range in our country is increasing on a yearly basis. Education services are planned and conducted in line with these data. In the 2019-2020 academic year, the number of Syrians at school age was 1,082,172. The number of Syrian students who were provided with access to education was 684,919 in 2019-2020. The number of Syrian students who were given access to formal education was determined as $50.82 \%$ for male $(348,103)$ and $49.18 \%(336,816)$, for female students, whereas the number of female students at middle school level was 109,875 and male students 113,307 (MNE, 2020).

The refugee reality experienced in Turkey has revealed the necessity to implement a strategic planning at the Ministry of National Education (MNE) related to refugee children. This plan includes activities planned to overcome the existing obstacles for the adaptation of refugees to the education system, international cooperation agreements and educational activities at national level. Syrian students are entitled to receive education in Turkish in Turkey with their peers (Baloğlu Uğurlu \& Akdovan, 2019; Unal Gezer, 2019).

Although each discipline area has a distinct place in terms of social adaptation of refugees in educational institutions, Social Studies is one of the courses that emphasize the teaching of social values the most in terms of content. The Social Studies course tries to instill a sense of us, not me, in refugee children and this improves the sense of social belonging in refugee children. Moreover, learning about our history, geography and culture, learning written and unwritten social rules and adopting citizenship responsibilities will be effective in terms of their adaptation to Turkish society (Baloğlu Uğurlu \& Akdovan, 2019).

Children with backgrounds and traditions belonging to different societies will share the same learning environment, use the knowledge, skills, values and attitudes they have acquired in the Social Studies course in their own communication environments and will internalize peace and tolerance, which are indispensable for a society, and transfer them to their own lives. It should not be forgotten that Social Studies has a curriculum that includes some current social issues like global peace and has inherent potential for solving some social and global problems (Odia, 2014, cited in Baloğlu Uğurlu \& Akdovan, 2019). It can be said that teaching subjects of history, which is one of the most basic disciplines of the Social Studies course, which derives its content from social sciences, is important for integrating students from different cultures into the society they live in. Therefore, the purpose of the present research is to determine the perceptions of middle school students who are refugees in Turkey about the subjects taught in history classes.

When the literature related to the subject under investigation is examined, it is seen that many studies have been conducted on refugees (Ardıç-Çobaner, 2015; Balkar, Şahin \& Işıklı Balaban, 2016; Başar, Akan \& Çiftçi, 2018; Börü \& Boyacı, 2016; Kağnıc1, 2017; Kara, Yiğit \& Ağırman, 2016; Er \& Bayındır, 2015; Erdem, 2017; Kolukırık, 2009; Özer, Komşuoğlu \& Ateşok, 2016; Mercan-Uzun \& Tüm, 2016; Palaz, Çepni \& Kılcan, 2019; Sakız, 2016; Şeker \& Aslan, 2015; Topkaya \& Akdağ, 2016; Yurdakul \& Tok, 2018; Zaimoğlu-Öztürk, 2018; Baloğlu Uğurlu \& 
Akdovan, 2019; Ablak, 2020). However, there is no study in the literature in which refugee students were directly included as samples. Therefore, it is hoped that our research will serve as a basis for new studies.

\section{Method}

This study was designed in the phenomenology model, which is one of the qualitative research methods. The phenomenology model is a highly suitable model for studying both emotional and effective and intense experiences (Merriam, 2018). In phenomenological studies, it is aimed to bring the individual experience associated with a case to a general level. In addition, these studies help reveal and interpret personal perceptions (Creswell, 2007; Yıldırım \& Şimşek, 2013). Therefore, phenomenology was used in this study, which aimed to reveal the perceptions of middle school students who were refugees in Turkey regarding the topics of history taught.

\section{Sample}

The sample consisted of 58 Syrian students ( 28 female and 30 male) legally registered in the Gaziantep province of Turkey and attending middle school $7^{\text {th }}$ and $8^{\text {th }}$ grades during the 2019-2020 academic year. The convenience sampling method was used in the study in the selection of the middle schools, and criterion sampling, which is one of the purposive sampling methods, was used in the selection of the sample from among the students in these schools. Criterion sampling "aims to work with individuals who meet pre-determined conditions" (Yıldırım \& Şimşek, 2013). The main purpose of using the convenience sampling method is "to provide speed and practicality to the researcher" (Büyüköztürk, Kılıç Çakmak, Akgün, Karadeniz \& Demirel, 2008). The criterion for the sample in this research was to be studying in the $7^{\text {th }}$ and $8^{\text {th }}$ grades in middle school, to be literate in Turkish and to be refugees in Turkey. In the determination of the sample, it was ensured that the participation of the students in the study was entirely on a voluntary basis.

\section{Data collection and analysis}

The research data were collected with a questionnaire form consisting of open-ended questions created by the researcher. While creating the questions, the relevant literature was examined and the opinions of faculty members who specialized in the field were utilized.

The data obtained from the research were subjected to descriptive analysis. The purpose of descriptive analysis is to interpret the obtained findings and present them to the readers in an orderly manner (Yıldırım \& Şimşek, 2013). In order to increase the reliability of the research, the analyses were conducted, apart from the researchers, with the help of two researchers, who were experts in their fields. For the reliability of the research, the formula $\mathrm{R}$ (Reliability) $=[\mathrm{Na}$ (Agreement 40) $/ \mathrm{Na}$ (Agreement 40) $+\mathrm{Nd}$ (Disagreement 3) $] \mathrm{x}$ 100, which was proposed by Miles and Huberman (1994), was used. According to the calculations made, the reliability was found to be $93 \%$ and the analysis of the research was accepted as reliable. In addition, the findings were supported by direct quotations from the students' opinions (S1: Student 1, S2: Student 2). 


\section{Findings}

5.1 Findings regarding which history subjects taught in the social studies course the students in the sample remembered

The students in the sample were first asked which history subjects they remembered from the social studies course. The answers given by the students are shown in Table 1.

Table 1 . The history subjects that the students remembered

\begin{tabular}{|l|c|}
\hline \multicolumn{1}{|c|}{ Codes } & f \\
\hline Ottoman History & 36 \\
\hline Culture and Heritage & 28 \\
\hline National Struggle & 25 \\
\hline History of the Republic & 14 \\
\hline Reformation-Renaissance & 11 \\
\hline Colonialism & 8 \\
\hline The Age of Enlightenment & 5 \\
\hline The French Revolution & 4 \\
\hline Central Asia & 3 \\
\hline The Seljuk State & 3 \\
\hline Ancient Civilizations & 2 \\
\hline Turkic World & 2 \\
\hline
\end{tabular}

Considering Table 1, it can be said that in general the students in the sample could recall history subjects in social studies. Since the sample consisted of $7^{\text {th }}$ and $8^{\text {th }}$ grade middle school students, it was observed that the students mostly mentioned the subjects of the period they studied, such as Ottoman History, National Struggle and History of the Republic. In addition, it was observed that the students gave the names of the units directly because the subjects they studied about history in the social studies course were given in the learning area of "Culture and Heritage". Some of the students' answers are as follows:

The subjects I remember from social studies are the subjects of Ottoman history and culture and heritage.

There are many things that I remember, but of the topics related to history, I can only list Ottoman history and Seljuks.

We studied a lot of subjects from history. When I think of history, Culture and Heritage comes to mind.

5.2 Findings about the subjects that interested the students the most from the history subjects taught in the social studies course

The students in the sample were asked which subject attracted the most attention among the history subjects they studied in the social studies course. The answers given by the students are shown in Table 2. 
Table 2. History topics attracting students' interest

\begin{tabular}{|l|c|}
\hline \multicolumn{1}{|c|}{ Codes } & f \\
\hline Ottoman History & 21 \\
\hline Life of Mustafa Kemal & 13 \\
\hline Topics with Ataturk & 11 \\
\hline The Conquest of Istanbul & 6 \\
\hline The History of Revolution & 5 \\
\hline Ataturkism & 2 \\
\hline
\end{tabular}

Considering Table 2, it is seen that one of the most interesting subjects among the history subjects that the students in the sample studied in the social studies course is again the subjects related to Ottoman history. After that, it can be said that the subjects of The History of Revolution attracted more attention from the students. Some students, on the other hand, cited the Conquest of Istanbul, which is also one of the subjects of Ottoman history, among the topics that also attracted their attention. It can be said that the students also associated the films they watched with the subjects that interested them. Some of the students' answers are as follows:

Studying Ottoman history sounds very interesting. Every era feels like an adventure movie. Indeed, their movies are also very interesting.

I am interested in every subject that involves Ataturk. Because he is a leading person.

The Conquest of Istanbul attracted me a lot because I had also watched a movie about it.

5.3 Findings regarding the subjects that the students had the most difficulty with from among the history subjects taught in social studies course

The students in the sample were asked which history subjects they had the most difficulty with from among the subjects they studied in the social studies course. The answers given by the students are shown in Table 3 .

Table 3. History subjects that the students had difficulty with

\begin{tabular}{|l|c|}
\hline \multicolumn{1}{|c|}{ Codes } & f \\
\hline Chronological information & 20 \\
\hline Wars & 15 \\
\hline Historical names & 13 \\
\hline Historical concepts & 8 \\
\hline Historical locations & 3 \\
\hline Ancient history subjects & 1 \\
\hline The Caucasian Front & 1 \\
\hline
\end{tabular}


Considering Table 3, it is seen that chronological information comes first among the subjects that the students in the sample had the most difficulty with from the history subjects they studied in the social studies course. In addition, it can be said that the students had difficulty with subjects such as wars and historical names, which are known as subjects requiring rote learning in history teaching. Some of the students' answers are as follows:

I get confused about historical names a lot and learning them is difficult.

I have a hard time learning the dates. I'm afraid they'll be on the exam. If they are asked, I will confuse them.

I have difficulty learning about wars. Actually, I can say that I don't like wars, I don't want to learn about them.

5.4 Findings regarding the opinions of the students about the treatment of the history subjects taught in the social studies course

The students in the sample were asked how the history subjects they studied in the social studies course were taught. The answers given by the students are shown in Table 4 .

Table 4. Students' assessment of the way the history course was taught

\begin{tabular}{|l|c|}
\hline \multicolumn{1}{|c|}{ Codes } & f \\
\hline Boring & 22 \\
\hline Constant test solving & 19 \\
\hline Not written on the board & 12 \\
\hline Reading from the book & 9 \\
\hline Requires memorization & 5 \\
\hline Plain teaching & 2 \\
\hline Very enjoyable & 6 \\
\hline
\end{tabular}

Considering Table 4, it is seen that the students in the sample generally used negative expressions such as "boring, continuous test solving, and reading from the book" regarding the teaching of the history subjects they studied in the social studies course. 6 students in the sample, on the other hand, used positive expressions about the course. It was found that the same teacher taught the classes of the students who used positive expressions and the students cited the teacher's name, saying his/her classes were enjoyable. Some of the students' answers are as follows:

In the history class, the teacher constantly does tests. It's like an exam preparation lesson. I am very overwhelmed.

The teacher is constantly reading from the book. If s/he does not read himself/herself, s/he makes us read it.

I love the social studies course. I wish every lesson was as enjoyable as Ayla teacher's lesson. 
5.5 Findings about the students' opinions regarding the certain historical events from the history subjects taught in the social studies course

The students in the sample were given 5 topics from the history subjects taught in the social studies course. The students were asked which subject they knew best and could teach. The answers given by the students concerning the subjects they preferred are shown in Table 5 .

Table 5. History subjects students knew best

\begin{tabular}{|l|c|}
\hline \multicolumn{1}{|c|}{ Subjects } & f \\
\hline Ottoman History & 26 \\
\hline National Struggle Period & 23 \\
\hline World War I Fronts & 11 \\
\hline Central Asian Turkish History & 10 \\
\hline Anatolian Civilizations & 6 \\
\hline
\end{tabular}

When the students in the sample were asked to choose one of the topics related to history, it was observed that the students preferred the Ottoman History and National Struggle Period more, which is in support of the previous findings, and they stated that they had more mastery of these subjects. Some of the students' answers are as follows:

I would have preferred subjects of Ottoman history. For I have more interest. Because I would like to better understand that period, since it ruled Syria and Iraq fairly for many years.

I prefer topics of national struggle. There are many lessons to learn from that struggle. I think it is an exemplary period for the whole world.

I prefer Anatolian civilizations. Because Anatolia is a key point for all humanity. I believe that understanding this geography well will shed light on the future.

5.6 Findings regarding the effect of history subjects taught in social studies course on students' perceptions of citizenship

The students in the sample were asked what the contribution of the history subjects they studied in social studies lessons was to their thoughts of citizenship. 37 of the students in the sample could not comment on the contribution of the history subjects to their citizenship perceptions. These students could not make an evaluation about the effect of the history subjects on their own thoughts of citizenship by giving answers such as "I don't know, I don't think so, and they didn't contribute much". The answers given by the other 21 students are shown in Table 6.

Table 6. Contribution of history subjects to students' patriotic thoughts

\begin{tabular}{|l|c|}
\hline \multicolumn{1}{|c|}{ Subjects } & f \\
\hline I became distanced/alienated & 17 \\
\hline I understood & 3 \\
\hline I appreciated & 2 \\
\hline I realized the truth & 1 \\
\hline I felt I belonged & 1 \\
\hline
\end{tabular}


According to Table 6, when the answers of the students in the sample who said that history subjects had an effect on their understanding of citizenship were examined, it can be said that there were those who stated that they became distanced from a feeling of citizenship because they could not learn their own history. Some of the students' answers are as follows:

In the history class, I learn the history of the country where I live. That is why I feel that I am becoming distanced from being a citizen of my own country.

As I study the subjects of history, I feel myself belonging here as much as my own country. Because, in fact, the solution of the problems my country is experiencing lies in the past.

Seeing the past mistakes in the history classes made the present more meaningful. Because my country and the country where I live have experienced many common events in the same geography.

\section{Conclusion and suggestions}

When we make a general evaluation of the results of this research, which aimed to reveal the perceptions of middle school students, who were refugees in Turkey, concerning the history subjects taught in social studies classes, it is possible to say that the students could remember the history subjects they had studied; subjects related to Ottoman History attracted their interest more; they found history classes boring, and the classes did not have much effect on their perceptions of patriotism. When we evaluate the results of the study in terms of subdimensions, the following results appear.

It can be said that the students in the sample could generally recall the history subjects in the social studies course. Since the sample consisted of $7^{\text {th }}$ and $8^{\text {th }}$ grade middle school students, it was observed that the students mostly cited the subjects of the period they studied, such as Ottoman History, National Struggle, and History of the Republic. In addition, it was observed that the students gave the name of the unit directly because the subjects they were taught about history in the social studies course were given in the learning area of "Culture and Heritage". It is possible to interpret this result as an indication that the students were interested in the lesson and could remember history subjects.

The subjects that attracted the most attention of the students in the sample from among the history subjects they studied in the social studies course were again those related to Ottoman History. Then, it can be said that the subjects of History of Revolution attracted more attention from the students. Some students also mentioned the subject of the Conquest of Istanbul, which is also among the Ottoman history subjects. It was determined that the students also associated the topics that interested them with the films they watched. Accordingly, it can be said that the students had an interest in Ottoman History, which covers a time period shared by their own country, as well as recent Turkish history. This interest can be attributed to the films they watched and their finding information about their country in Ottoman history. Moreover, when the students in the sample were asked to choose one of the topics related to history, it was seen that the students preferred Ottoman History and the National Struggle period more, which is in support of the previous findings. Moreover, they stated that they were more knowledgeable about these subjects. Likewise, the findings in Biçer's (2017) study indicate that Syrian refugees saw similarities between Turkish culture and their own culture, watched Turkish movies, listened to Turkish songs and knew Turkish traditions. We can say that these findings show that refugees had a positive approach to Turkish culture and they adopted various cultural elements.

Chronological information was one of the most difficult subjects that the students in the sample studied in the social studies course. In addition, it can be said that the students had difficulties with subjects such as wars and historical names, which are known to require rote 
learning in history teaching. It can be said that the students found the aspect of history that required memorization boring. The students in the sample also generally used negative expressions such as "boring, constantly doing tests, and reading from a book" about the treatment of the history subjects they studied in the social studies course. Similarly, Ulusoy (2009) concluded that students found history lesson boring because it was taught plainly and they felt uncomfortable with the subjects that required memorization. The fact that the findings of Ulusoy's study on Turkish students show similarities with the findings of this research conducted with refugees indicates that history lessons are still being taught in a plain and monotonous way for students in our schools. Moreover, it can also be considered that refugee students were reactive to wars as they found them repulsive as well as difficult, considering the reason for leaving their country. For example, in Aydin and Kaya (2017)'s study with teachers, one teacher observed, "I shouted in the middle of the classroom and my Syrian student covered his ears. I saw the fear in his eyes. Then I realized the fear the war brought them.” These statements support the findings of the present research. In Ulusoy's (2009) study, it was found that Turkish students did not feel uncomfortable about subjects related to war. This finding of Ulusoy can be interpreted to mean that Syrian students had difficulty with these subjects because they caused them to remember the negative experiences they had of the recent events. In the findings of the present study, it was also seen that 6 students in the sample used positive expressions about the treatment of history subjects. Considering the data of the students who used positive expressions, they stated that the same teacher taught the classes of these students and their classes were enjoyable. Although it was determined that the students found the history lesson boring, the fact that, of the students in the sample, the students in the class which the same teacher taught found history lesson enjoyable points to the role of the teacher in making the lesson popular.

When the students in the sample were asked what the contribution of the history subjects they studied in the social studies classes was to their thoughts about citizenship, 37 of the students could not make a comment about the contribution of the history subjects to their perception of citizenship. These students could not make an evaluation about the effect of history subjects on their own thoughts of citizenship by giving such answers as "I don't know, I don't think so, they did not contribute much". Of the 21 students who said that the history subjects had an effect on their understanding of citizenship, there were also those who said that they became distanced from an understanding of citizenship because they could not learn their own history. However, there were also some who cited the positive effects on their perception of citizenship by associating the history of their country with the history subjects they studied in our country. Considering the purpose of our research, this result can actually be interpreted to mean that the history subjects failed to achieve the desired goal, taking into account the importance of creating a sense of belonging in refugee students' perceptions of the citizenship during their school period. Similar to this result, Zayimoğlu-Öztürk (2018) revealed that social studies teachers thought that refugee students should first embrace the society they lived in and adapt to the cultural structure of the country. However, they found the content of the social studies lesson inadequate in terms of refugees' adaptation to our country. On the other hand, it is an important problem that refugee students in our country cannot develop a perception of homeland in their minds during school age. Dryden-Peterson (2020) indicated that a refugee student was in a dilemma with questions like "What will my life be if I integrate as a citizen of this country? Would it be better or worse than I was in the refugee camp?". The words of a refugee student in Aydın and Kaya (2017) reading "I am in a different place, I live in a different country. But my heart remained in Syria" reveal the uncertainty they experienced during their school years.

In the 1951 Geneva Convention, the refugee was defined as a stateless person residing in a different country for fear of persecution for reasons of race, religion, nationality, political opinion or other reasons (Geneva Convention, 1951). The expression "stateless" in this definition should in fact be considered, as Ilcan (2018) stated, indicating that responsible citizenship education and good citizenship education should aim to instill socially acceptable behaviors in 
refugees in a supportive environment. For students experience problems in adapting to the school culture and therefore to the society they live in at school age. For example, Başar, Akan and Çiftçi (2018) revealed in their study that teachers stated that refugee students had communication problems because they faced linguistic barriers in the learning process. Likewise, Caniglia (2018) emphasized that teachers from various disciplines stated that they had difficulties in preparing refugee students for academic and professional education. Reinking (2019), on the other hand, revealed that refugee children often experienced interruptions in allocating time to school. Considering all these problems, it may be suggested that social studies course and especially history subjects in the middle school period should be organized in a way to help students' adaptation, or to help refugee students to integrate into the country with different activities during the classes. In addition, academic studies should be conducted in this regard, especially with refugee students as sample, and steps should be taken in every sense in education in their favor by clarifying the problems and the relations of students in different fields.

\section{Acknowledgements}

This research did not receive any specific grant from funding agencies in the public commercial, or not-for-profit sectors.

The author declares no competing interests.

\section{References}

Ablak, S. (2020). Attitudes of secondary school students towards refugee students. International Journal of Psychology and Educational Studies, 7(3), 101-110.

Ardic-Cobaner, A. (2015). Representation of Syrian refugee children in news in the context of children rights. Marmara Journal of Communication, 24, 27-54. https://doi.org/10.17829/midr.20152419996

Aydin, H., \& Kaya, Y. (2017) The educational needs of and barriers faced by Syrian refugee students in Turkey: A qualitative case study, Intercultural Education, 28(5), 456-473, https://doi.org/10.1080/14675986.2017.1336373

Balkar, B., Şahin, S., \& Işılkl Babahan, N. (2016). Problems confronted by Syrian teachers working at temporary education centers (TECS). Journal of Theory and Practice in Education, 12(6) 1290-1310.

Baloğlu Uğurlu, N., \& Akdovan, N. (2019). Refugee students from the perspective of social studies teachers. Bolu Abant Izzet Baysal University Journal of Faculty of Education, 19(3), 782-801.

Başar, M., Akan, D., \& Çiftçi, M. (2018). Learning-teaching process issues in classrooms with refugee students. Kastamonu Education Journal, 26(5), 1571-1578. https://doi.org/10.24106/kefdergi.427432

Biçer, N. (2017). The views of Syrian refugees migrating to Turkey on the Turkish language and culture: Kilis case. Journal of Education and Training Studies, 5(3), 97-109.

Börü, N., \& Boyacı, A. (2016). Immigrant students' problems in education-instruction processes (an example of the province of Eskisehir). International Periodical for the Languages, Literature and History of Turkish or Turkic, 11(14), 123-158.

Büyüköztürk, Ş. Çakmak, E. K. Akgün, Ö. E. Karadeniz, Ş., \& Demirel, F. (2010). Bilimsel araştırma yöntemleri [Scientific research methods]. Ankara: Pegem A Yayıncılık. 
Caniglia, J. (2018) Teaching function mathematics skills to refugees. Adults Learning Mathematics: An International Journal, 13(1), 7-16.

Creswell, J. W. (2007). Qualitative inquiry and research design choosing among five approaches. Sage Publications.

Dryden-Peterson, S. (2020) Civic education and the education of refugees. Intercultural Education, 31(5), 592-606. https://doi.org/10.1080/14675986.2020.1794203

Er, A. R., \& Bayındır, N. (2015). Pedagogical approaches of elementary teachers for primary refugee children. International Journal of Social and Educational Sciences, 2(4), 175-185.

Erdem, C. (2017). Instructional problems experienced by primary school teachers who have refugee students in their classes and their solutions for problems. Journal of Civilization Educational Research, 1(1), 26-42.

Geneva Convention (1951). Retrieved from http://www.multeci.org.tr/wp-content/uploads/2016/12/1951Cenevre-Sozlesmesi-1.pdf.

Gümüşten, D. (2017). Review on intervention programs for refugee children's education and adaptation. Nesne-Journal of Psychology, 5(10), 247-264.

Ilcan, S. (2018). The humanitarian-citizenship nexus: the politics of citizenship training in self-reliance strategies for refugees. Geografiska Annaler: Series B, Human Geography, 10o(2), 97-111. https://doi.org/10.1080/04353684.2018.1453754

Kağnıcı, D. Y. (2017). School counselors' roles and responsibilities in cultural adaptation process of Syrian refugee children. Elementary Education Online, 16(4), 1768-1776.

Kara, Ö. T, Yiğit, A., \& A ğırman, F. (2016). The study of the perceptıons of the students studyıng in the department of turkısh teachıng in Çukurova unıversıty about the term "Syrian refugee". Journal of Theory and Practice in Education, 12(4), 945-961. https://doi.org/10.17051/ilkonline.2017.342990

Kılcan, B., Çepni, O., \& Kılınç, A. Ç. (2017). Development of the attitude towards refugee students scale. Journal of Human Sciences, 14(2), 1045-1057. https://doi.org/10.14687/jhs.v14i2.4324

Kiwan, D. (2021) Inclusion and citizenship: Syrian and Palestinian refugees in Lebanon. International Journal of Inclusive Education, 25(2), 283-297. https://doi.org/10.1080/13603116.2019.1707308

Kolukırık, S. (2009). Image of refugees and asylum-seekers in the media: an evaluation on media politics. Gaziantep University Journal of Social Science, 8(1), 1-20.

Le, H. M. (2019). Private encroachment through crisis-making: The privatization of education for refugees. Education Policy Analysis Archives, 27(126). https://doi.org/10.14507/epaa.27.4325

MEB (2020). Ylllara göre ülkemizde bulunan geçici koruma altındaki Suriyeli nüfus [Syrian population under temporary protection in our country by years.]. MEB. Hayat Boyu Öğrenme Genel Müdürlüğü Göç ve Acil Durum Eğitim Daire Başkanlı̆̆ı Bülteni. https://hbogm.meb.gov.tr/meb iys dosyalar/2020 01/27110237 OCAK 2020internet Bu lteniSunu.pdf (Downloaded on 15 January 2021).

Mercan Uzun, E., \& Bütün, E. (2016). Teachers' views on the problems faced by Syrian refugee children in preschool education institutions. International Journal of Early Childhood Education Studies-IJECES, 1(1), 72-83.

Merriam, S. B. (2018). Nitel araştırma/desen ve uygulama için bir rehber (3. Baskı, Çev. S. Turan). Ankara: Nobel Yayınevi.

Miles, M. B., \& Huberman, A. M. (1994). Qualitative data analysis: An expanded sourcebook (2 ${ }^{\text {nd }}$ ed.). Thousand Oaks, CA: Sage.

Özer, Y. Y., Komşuoğlu, A., \& Ateşok, Z. Ö. (2016). Education of Syrian children in Turkey: Problems and suggestions. The Journal of Academic Social Science, 4(37), 34-42. 
Palaz, T., Çepni, O., \& Kılcan, B. (2019). Secondary school students' opinions and attitudes on refugee students. Turkish Studies Educational Sciences, 14(3), 1661-1684. https://doi.org/10.29228/TurkishStudies.22631

Reinking, A. K. (2019). Addressing the needs of refugee students in school environments: Pre and post arrival considerations. New Waves Educational Research \& Development, 22(1), 14-26.

Sakız, H. (2016). Migrant children and school cultures: A suggestion for inclusion. Migration Journal, 3(1) 65-81.

Seker, B. D., \& Aslan, Z. (2015). Refugee children in the educational process: A social psychological assessment. Journal of Theoretical Educational Science, 8(1), 86-105. https://doi.org/10.5578/keg.8234

Taskin, P., \& Erdemli, O. (2018). Education for Syrian refugees: Problems faced by teachers in Turkey. Eurasian Journal of Educational Research, 75, 155-178. https://doi.org/10.14689/ejer.2018.75.9

Tezel McCarthy, A. (2018). Politics of refugee education: Educational administration of the Syrian refugee crisis in Turkey. Journal of Educational Administration and History, 5O(3), 223-238.

Topkaya, Y., \& Akdağ, H. (2016). Prospective social studies teachers' views about Syrian defectors (Kilis 7 Aralık University Sample). Cankiri Karatekin University Journal of Institute of Social Sciences, 7(1), 767-786.

Ulusoy, K. (2009). High school students' views about instructıon of history lessons (A case study in Ankara). Ç.Ü. Journal of Social Sciences Institute, 18(1), 417-434.

Ünal Gezer, M. (2019). Looking through the multicultural glass: Re-examination of Syrian refugee children education in Turkey. Eurasian Journal of Applied Linguistics, 5(2), 303-322. https://doi.org/10.32601/ejal.599275

Yıldırım, A., \& Şimşek, H. (2013). Sosyal bilimlerde nitel araştırma yöntemleri (9. Baskı) [Qualitative research methods in the social sciences]. Ankara: Seçkin Yayıncılık.

Yurdakul, A., \& Tok, T. N. (2018). Migrant/refugee student from the view of teachers. Adnan Menderes University Journal of Educational Sciences, 9(2), 46-58.

Zayimoğlu-Öztürk, F. (2018). Evaluation of educational service provided for refugee students according to social studies teachers' opinions. Anadolu Journal of Educational Sciences International, 8(1), 52-79. https://doi.org/10.18039/ajesi.393879 